\title{
"O que quer uma mulher": figuras femininas em Eles eram muitos cavalos
}

\author{
Helena Bonito Couto Pereira ${ }^{1}$
}

O mineiro Luiz Ruffato iniciou sua carreira de escritor em 1984, com os poemas de Cotidiano do medo, a que se sucederam outras publicações de contos. Foi contemplado com o Prêmio Casa de las Américas, em 2001, por (os sobreviventes), e a partir daquele ano, com a publicação de Eles eram muitos cavalos, ${ }^{2}$ passou a receber destaque em nossas letras.

O título do fragmento 10 do livro, "O que quer uma mulher", foi escolhido como ponto de partida para estas reflexões em torno de figuras femininas que fazem parte do grande mosaico da capital paulistana elaborado por Ruffato. Impõe-se de imediato uma questão: as figuras femininas, presentes em quase todos os 70 fragmentos da obra, são mesmo personagens romanescas? Antes ainda: pode-se inserir EEMC no gênero romance? Tais questões remetem diretamente à dificuldade para classificar essa narrativa desafiadora, como observa Fanny Abramovich no texto da orelha da 3a edição da obra: "Não sei se li um romance ou novela, se contos, registros ou espantos" (Ruffato, 2005). Ou, nas palavras de Macedo, "EEMC é um livro que desafia qualquer categorização, em termos de escola literária" (2007, p. 53).

Usualmente filiado ao gênero "romance" em premiações, nos catálogos de editoras e livrarias, em sites e nos demais veículos que tratam de literatura, EEMC tem sido reconhecido como romance também por críticos literários, como Schøllhammer (2011, p. 79-83) e Harrison (2008, p. 9-17), entre outros. A fortuna crítica de Ruffato cresce continuamente, sendo esta a sua obra de maior repercussão, não só no mundo acadêmico, como demonstram as numerosas traduções para outras línguas. A afirmação sobre o gênero merece discussão, pois um romance tradicional conta com protagonistas bem definidos, trama cerrada e aprofundamento em questões psicológicas, existenciais ou sociológicas. Segundo Candido et al. (1995, p. 45), o romance é o texto em que personagens estão

\footnotetext{
${ }^{1}$ Doutora em letras e professora no Programa de Pós-Graduação em Letras da Universidade Presbiteriana Mackenzie, São Paulo, SP, Brasil. E-mail: helena.pereira@ mackenzie.br

${ }^{2}$ Daqui em diante, EEMC.
} 
integradas em um denso tecido de valores de ordem cognoscitiva, religiosa, moral, político-social, e tomam determinadas atitudes em face desses valores. Muitas vezes debatem-se com a necessidade de decidir-se em face da colisão de valores, passam por terríveis conflitos e enfrentam situações-limite, em que se revelam aspectos essenciais da vida humana; aspectos trágicos, sublimes, demoníacos, grotescos ou luminosos.

Pelo enredo fragmentário e pela profusão de personagens, dificilmente estas últimas poderiam ser consideradas "integradas em um denso tecido de valores", pois são apresentadas ao leitor sem preâmbulos, em breves pinceladas, atuando em fragmentos sem conexões entre si, quase sempre em ambientes violentos, sórdidos ou hostis, nesses espaços apenas esboçados na simultaneidade de um único dia. Mesmo que seja impossível atingir algum aprofundamento, em virtude de sua natureza de mosaico, em quadros-síntese justapostos, pode-se aproximar essa narrativa desconstruída do que se define habitualmente como romance. Suas personagens, em geral pouco descritas e não nomeadas, revelam-se em seus "aspectos trágicos, sublimes, demoníacos, grotescos ou luminosos", em conformidade com o dizer de Candido. Outro aspecto presente nessa narrativa é a mobilização de valores em conflitos que, sumariamente esboçados, exigem posicionamento das personagens em face de seus valores.

$\mathrm{Na}$ convulsionada metrópole que tudo devora ou descarta, encenando um ritual de sucessivas destruições - da integridade, de valores, das identidades, do convívio social -, subjaz uma sólida articulação que produz efeitos semelhantes aos do grande romance. Isso porque as situações narradas suscitam reflexões em torno dos mistérios do ser humano e das contingências - ou constrangimentos - com que cada um pode se defrontar no contexto urbano contemporâneo. Nessa narrativa em que as personagens são contempladas em instantâneos, como se uma câmera fotográfica as captasse furtivamente, ou como se fosse a produção de um clipe, o protagonista indiscutível é a metrópole que pulsa, violenta, indomável, nas vinte e quatro horas de um dia bem definido, 9 de maio de 2000.

Ruffato cria um mosaico disforme e desproporcional como a metrópole, encenando a deriva de um grande elenco, composto de personagens instáveis que parecem movimentar-se simultaneamente, em cenários tão variados quanto uma casa na esquina da avenida 
Rebouças com a rua Estados Unidos, a arquibancada do Estádio Pacaembu, a praça da Sé, o largo São Francisco, o boteco no ponto final da linha 6086 (Jardim Varginha-Santo Amaro), a "boca da favela", a escola infantil depredada por vândalos, e assim por diante. Ambientes de periferia predominam em relação a raros espaços "burgueses", assim como personagens da classe média ou baixa e das esferas de exclusão social encontram-se em maior número em relação a personagens bem situadas econômica e socialmente. Seja qual for a classe social ou o ambiente, predominam personagens marcadas por tristeza, amargura, desesperança. Mais raras, as personagens associadas ao mundo dos abastados ou dos políticos protagonizam situações sórdidas, caso do prefeito que "não gosta que lhe olhem nos olhos" (2000, p. 96) ou do político cujo assessor organiza suas festas, regadas a uísque e cocaína, com garotos e garotas de programa (2000, p. 107-109).

Em meio à profusão - justificada - de textos críticos e interpretações suscitadas por EEMC, as figuras femininas constituem um componente até aqui pouco explorado. Tais figuras coexistem em uma variedade surpreendente, em termos de faixa etária, condições socioeconômicas, objetivos de vida e dificuldades ou impasses no instante em que são capturadas pelas lentes desse narrador, que vaga como verdadeiro fotógrafo em busca dos flagrantes da vida na metrópole. As variadas formas que o narrador assume, sem abandonar sua onisciência, dando voz, eventualmente, às personagens, constituem um notável exercício de criatividade. A participação feminina nesses fragmentos ou episódios é narrada por meio de focos narrativos variados: em terceira pessoa, com ou sem diálogos, em discurso indireto livre, por meio de bilhete, carta ou gravação.

O que é uma personagem? Wood (2011, p. 94) problematiza a questão, considerando que "um personagem parece estar ligado à consciência, a um funcionamento mental", embora haja magníficos personagens que parecem pensar muito pouco; uma personagem também "guarda pelo menos alguma ligação essencial com uma vida interior, com a introspeção", embora tantas personagens sejam bem caracterizadas externamente, com pouco espaço reservado à reflexão. Ainda segundo o crítico, personagens são entes extremamente variáveis, e assim devem ser compreendidas:

Não existe esse negócio de "personagem de romance". Existem, isso sim, milhares de tipos diferentes de pessoas, algumas 
redondas, outras planas, algumas profundas, outras caricaturais, algumas evocadas com realismo, outras esboçadas com a mais leve pincelada. [...] Meu gosto pessoal pende para o personagem apenas esboçado, cujas omissões e lacunas nos intrigam, fazendonos entrar em suas superficialidades profundas (2011, p. 95).

Adiante, determinando que todo personagem tem "uma realidade", que, entretanto, funciona de modo diferente em cada obra, o mesmo crítico aponta para a necessidade de que o leitor consiga adaptar-se às convenções internas do livro:

Creio que os romances tendem a falhar não quando os personagens não são vívidos ou profundos o suficiente, e sim quando o romance em questão não nos ensina como nos adaptar a suas convenções, não desperta uma fome específica por seus personagens, por seu grau de realidade (2011, p. 105)

Cabe ao leitor, portanto, adaptar-se às "convenções" internas do livro e, nesse caso, usufruir EEMC como romance, sempre levando em conta que nessa narrativa em mosaico, de enredo desconstruído, verdadeira colagem de retratos do cotidiano da metrópole, não há protagonistas em dramas existenciais aprofundados ao longo do tempo, nem situações dramáticas construídas lentamente. Nessa perspectiva, muitas das personagens (não apenas as femininas, evidentemente) podem ser lidas como personagens de um romance portador de um excepcional "grau de realidade".

Outro aspecto da narrativa de Ruffato consiste em sua proximidade com o nouveau roman, tendência que esteve em voga na França na década de 1960, e cuja presença na romanesca contemporânea ainda está por ser explorada. Segundo Lagarde e Michard (1988)

O novo romance não se apresenta como uma explanação ou uma relação linear, mas como uma busca. Um constante vaivém no tempo, a justaposição de instantâneos, versões divergentes da mesma cena, a presença obsessiva de objetos, um "duplo movimento de criação e de colagem" podem desconcertar o leitor; mas este último deve compreender que o autor espera dele uma participação ativa (1988, p. 762, tradução nossa).

Ecos do nouveau roman evidenciam-se em alguns fragmentos, em especial no "32. Uma copa", comentado adiante. Em EEMC, a narrativa não linear não se faz acompanhar de um vaivém no tempo, 
porém a simultaneidade das ações em um único dia não deixa de compor, ao lado de outras marcas estilísticas do nouveau roman, um painel cheio de indagações propostas ao leitor, exigindo uma participação ativa de sua parte.

Após as observações iniciais sobre as peculiaridades dessa narrativa de Ruffato, este estudo volta suas atenções para as figuras femininas, apresentadas por um narrador onisciente que assume várias modalidades de focalização. Ora as encontramos como protagonistas ("6. Mãe", "15. Fran”, “38. A menina”, “39. Regime”), ora como narradoras, por meio de sua voz ("58. Malabares"), em correspondência ou em bilhete ao filho (“50. Carta”) ou, ainda, numa gravação ("25. Pelo telefone”), ora em breve alusão ("33. A vida antes da morte"). Podem mesmo ser narratárias, ainda que ausentes da narrativa ("62. Da última vez") ou, paradoxalmente, marcar-se pela ausência ("32. Uma copa"). Nos papéis que desempenham em cada fragmento, ressalta-se a diversidade de estilos, que constitui um dos fatores da riqueza dessa narrativa.

O primeiro fragmento que alude a uma figura feminina, “3. Hagiologia" (EEMC, p. 11), resume-se a uma minibiografia de Santa Catarina de Bolonha. O conteúdo remete a antigos calendários católicos, colados em 365 pequenas folhas, uma para cada dia do ano, com as informações referentes ao "santo do dia". Encontra-se aí uma reminiscência de um Brasil ancestral, profundamente católico, com a população distribuída em pequenas cidades ou vilarejos, cuja vida estava indissoluvelmente associada aos ritos e às comemorações da Igreja Católica. Talvez uma reminiscência do que desapareceu na vida urbana, na sociedade de consumo, em que a religiosidade muitas vezes se transforma em ritual vazio ou mero espetáculo.

Já no fragmento seguinte, "4. A caminho", a personagem feminina é apenas o alvo da busca do protagonista, um indivíduo que enriqueceu rapidamente por meios ilícitos e "cuida do caixa-dois da corretora", e que está a caminho do aeroporto, em busca da jovem que "desembarca london-gatwick um anel adquirido na portobello road na palma da mão" (EEMC, p. 13). Como essa, outras mulheres desfilam anônimas, reificadas nesse contexto de busca do prazer imediato e descartável. No fragmento 51, um "assessor" de um deputado explica uma parte de seu trabalho:

Eu vou numa casa em Moema [...] aí eu ponho três mulheres pra dentro [do carro], das melhores, só universitária [...] uma vez levei até uma que era capa da revista Sexy, não sei se você 
conhece, o deputado olhou e falou, essa menina frequenta lá, vê se traz, eu levei, puta-que-pariu!, precisava ver que mulherão (EEMC, p. 108-109).

São anônimas também figuras a quem se refere o narrador do episódio "55. Via internet", vangloriando-se de suas conquistas, já que, em sua opinião, "no fundo no fundo as mulheres só querem ser comidas por um cara carinhoso, romântico" (EEMC, p. 115).

Expostas na escrita desse narrador que se expressa quase sempre em terceira pessoa e que emprega, com muita propriedade, o discurso indireto livre, as personagens femininas de EEMC atuam diante dos olhos do leitor de variados modos. O mais usual, sem dúvida, é o do narrador onisciente, que domina a consciência e os pensamentos das personagens. Ante o expressivo número de personagens femininas em diferentes situações, o estudo contempla algumas delas a partir de dois tipos de espaços narrativos em que se encontram: em trânsito e em "não lugares", ou no recesso do lar.

\section{Em trânsito e em "não lugares"}

Mãe

O fragmento "6. Mãe" (EEMC, p. 16-18) narra a viagem de uma avó, acompanhada de seu neto, de Garanhuns a São Paulo, apresentando seu mal-estar físico ("sem posição", "bexiga espremida, intestino solto"), sua inquietação com a velocidade ("Meu Deus, pra que tanta correria?"), suas recordações do filho que se mudou para São Paulo e só retornou ao Brejo Velho duas vezes, quando ainda era solteiro. $O$ fragmento apresenta variados recursos estilísticos, que compreendem distribuição de intertítulos, termos e frases em negrito, em itálico ou em ambos, enumerações caóticas, reiterações, aliterações, onomatopeia, orações incompletas sem pontuação, seguidas de outras cuja conexão cabe ao leitor descobrir. Não menos variadas são as vozes que se alternam: o narrador, a "Mãe", em discurso direto ou indireto livre, seus possíveis interlocutores - o neto, o motorista do ônibus.

Praticamente todos os recursos estilísticos referem-se ao mal-estar, à desambientação da protagonista nessa viagem, para ela, infindável. $\mathrm{O}$ primeiro intertítulo reduz-se a uma conjunção - "E" - que introduz a enumeração caótica da paisagem. Sobressaem as aliterações e reiterações, responsáveis por algum fundo poético à rudeza do entorno: 
"[...] bois, burros, bestas, botinas, brejos, beirais, bodes, bosta, baratas, bichos, bananeiras, bicicletas, arvrinhas, árvores, árvores, árvores" (EEMC, p. 16). O segundo intertítulo apresenta uma onomatopeia em negrito, seguida novamente do " $\mathrm{E}$ ": "o motor zunindo em-dentro do ouvido (zuuuuummm)", seguindo-se mais três intertítulos, o último dos quais deixa de enumerar e passa a descrever cenas, sempre na perspectiva da protagonista, às quais se acrescentam seus pensamentos, em discurso indireto livre, e sua interlocução com o neto:

brancas vacas no verdor do pasto, sáfaras nuvens, roupa seca, carne-seca, terras, terras, terras, o vento, o dia verde-quente, a tarde azul-frienta, a noite de estrelas empoeiradas, o mundo, mundo grande, que não se acaba mais nunca e Ô vovó alá as luzes de São o filho esperando Tantos anos! Ganhar a vida em Sampaulo, no Brejo Velho Duas vezes só, voltou, meu Deus, e isso em solteiro (EEMC, p. 17).

Nesse fragmento sobressai o domínio de Ruffato sobre a linguagem, no sentido de mobilizar seus efeitos para conferir alguma poeticidade ao ambiente áspero, rude, hostil. E, ao final, persistem as preocupações da mãe, que chega enfim a seu destino: "[...] como ler o olho do filho? Saber se é feliz no trabalho, no casamento, se, mas, $A i$, a bexiga, a barriga, as costas, Ai!, as escadeiras, Ui!, as pernas, Ai!, Ui!, sem posição. Na rodoviária, de pé, esfrega as mãos" (EEMC, p. 18).

Em relação às figuras femininas em EEMC, vale ressaltar que essa é a mais idosa. O narrador apresenta seus desconfortos físicos, suas dificuldades com o ônibus ("o empesteado ar de janelas fechadas, vidros suados, no soalho, esparramados, papéis de bala, de bolacha, guardanapos, sacolas, palitos de picolé, copos descartáveis, garrafas plásticas, farelo de biscoito-de-polvilho, de pão, de broa, farinha, restos de comida"). Esse desconforto físico e mental se sobrepõe ao motivo da viagem, rever familiares e comemorar o dia das mães. A possibilidade de momentos felizes que compensem todo esse desconforto é relegada ao futuro, pois o fragmento termina com sua chegada à rodoviária. Esse é, aliás, um recurso recorrente: melhores dias, quando há qualquer perspectiva de que venham a ocorrer, não fazem parte do mundo narrado.

Outro aspecto relevante no fragmento 9 é a sensação de desterramento da protagonista, que está em trânsito entre o lugarejo em que vive e a metrópole desconhecida. Segundo Augé, as sociedades modernas - aí incluídas as pequenas cidades -, "a localização no tempo 
e no espaço é [...] fácil de efetuar: ela vale para todos" (2012, p. 49), havendo, portanto, visível afinidade entre cultura, sociedade e indivíduo. Alguns fatores, como o esvaziamento da individualidade, diluída na velocidade das imagens, em que a própria identidade deixa de fazer sentido, contribuíram para o surgimento do que Augé define como supermodernidade, contexto em que se instalam os "não lugares":

Por "não lugar" designamos duas realidades complementares, porém distintas: espaços constituídos em relação a certos fins (transporte, trânsito, comércio, lazer) e a relação que os indivíduos mantêm com esses espaços. Se as duas relações se correspondem de maneira bastante ampla e, em todo caso, oficialmente (os indivíduos viajam, compram, repousam), não se confundem, no entanto, pois os não lugares medeiam todo um conjunto de relações consigo e com os outros que só dizem respeito indiretamente a seus fins: assim como os lugares antropológicos criam um social orgânico, os não lugares criam uma tensão solitária (Augé, 2012, p. 87).

O esvaziamento da individualidade e a diluição das personagens no turbilhão da metrópole reiteram-se na quantidade de fragmentos que têm por cenário espaços abertos, ruas ou, ainda, personagens em trânsito. Além dos que se comentam neste estudo, fragmentos com títulos como "4. A caminho", ou "66. Rua" explicitam exatamente o movimento. Outros indicam lugares externos, como "23. Chegasse o cliente", que se passa diante de um restaurante, ou "11. Chacina no 41" (título autoexplicativo), ou ainda "45. Vista parcial da cidade", em que o narrador se pergunta: "(são paulo é o lá fora? é o aqui dentro?" (EEMC, p. 95).

\section{Aquela mulher}

$\mathrm{O}$ "não lugar" é também o espaço em que vive a personagem do fragmento “34. Aquela mulher" (EEMC, p.70-71). A personagem é moradora de rua, vivendo, portanto, em um "não lugar". Andarilha sem nome, a protagonista é "aquela mulher que se arrasta, espantalha, por ruavenidas do morumbi." (p. 70) Essa frase de abertura, sempre com inicial minúscula, reitera-se do mesmo modo nos quatro parágrafos seguintes. Cada um deles contribui para a caracterização dessa figura, verdadeira personificação do abandono e da loucura, cujos motivos surgem adiante. 
No primeiro parágrafo, o narrador a apresenta por metonímias sempre adjetivadas, em escrita acelerada pela ausência de vírgulas: "cabelos assim espetados na imundície olhos assim perturbados pele ruça agitadas pernas braços assim machucados unhas pretas vestido esfrangalhado" (p. 70). Nos dois parágrafos seguintes, o narrador a apresenta em movimento "fala desconforme baba espumando", e acrescenta detalhes metonímicos: "lábios murchos olhar esgotado mãos que pendulam arrítmicas pernas desaprumadas", "inconveniente suplicando respostas exigindo febril irritada chorosa perguntas variantes insensas" (p. 70). A seguir, a oração em reiteração introduz detalhes do ambiente: ratos, baratas, sapatos, tênis, havaianas; o quinto parágrafo limita-se ao trecho reiterado, a que se seguem três parágrafos simulando versos: "não era assim/não/não era" (p. 71).

Essa paráfrase tem o intuito de evidenciar o modo de construção da personagem: a personagem excluída, "espantalho" do que teria sido, compõe-se de metonímias de seu corpo praticamente desintegrado, correspondente a seu estado interior, em um ambiente que é o "lado B" do Morumbi, um dos bairros mais elegantes de São Paulo. Da mesma forma, a reiteração das negações, a seguir, introduz outro movimento na narrativa, sobre os fatos que a levaram à loucura: o desaparecimento da filha, narrado em detalhes, sucessivamente, a exteriorizar a intensidade desses momentos decisivos na vida da personagem.

Enquanto a protagonista de "Mãe" exprime sua angústia ao chegar na metrópole, "aquela mulher", enlouquecida, reificada, permanece na metrópole, em situação de abandono e exclusão, sofrendo os efeitos da violência. As ruas são "não lugares" por excelência, espaços de trânsito e de indiferença em relação ao próximo.

\section{Noite}

Também no fragmento 61, o espaço ficcional se constitui em um "não lugar", o espaço da rua em que uma pequena vendedora de dropes se dirige ao narrador que vai a um restaurante. De início, ele a descreve como muito jovem, "menina, aposto que nem quinze anos" (EEMC, p. 125), de um modo que causa alguma estranheza: "O cabelo espichadohenê, rabo-de-cavalo amansado, elástico vermelho. Vestidinho branco, asseadíssimo, pequenas flores alto-relevo bordadas alto do peito, os pés, sandália de plástico transparente, oferecem dropes mistos a um e outro, lindo sorriso alvo." O branco, a limpeza, a transparência parecem 
incompatíveis com sua situação de vendedora na rua, à noite. Ele lhe oferece uma refeição no Habib's, que ela devora "estupidamente, metafisicamente" (p. 126) e depois continua a oferecer dropes a uns e outros na calçada. O narrador-personagem segue seu caminho "cadê Marina?, não vai passar nunca esse mal-estar, nunca essa sensação de inutilidade, Marina! Marina!" (p. 126), manifestando nesse fragmento, subitamente, um mal-estar e uma sensação de inutilidade decorrentes de um sentimento de solidariedade e de inquietação quanto ao futuro da jovem. A percepção do mal estar, todavia, não conduz a uma ação, a alguma tentativa de resgatá-la da precariedade em que se encontra.

\section{(Ela}

Ainda em um "não lugar", o centro velho da cidade de São Paulo, transcorre a ação do fragmento 22, em que uma jovem, atravessando galhardamente ruas sujas e degradadas, exerce o papel de contraponto às dificuldades e misérias com que se deparam os habitantes da metrópole praticamente em todo o livro. Também está em um espaço de passagem, de trânsito, propício à solidão, pois na balbúrdia ruidosa do centro velho da cidade, ninguém se comunica verdadeiramente.

Essa incomunicabilidade não afeta a jovem, habituada a percorrer esse espaço. A ela se associam leveza e harmonia, representadas, em hipálage, pelo seu calçado, e pelo ambiente: “Tão leve em seus dezesseis anos, cirurgicamente levita o tênis milímetros das pedras portuguesas que a rua Direita forram" (EEMC, p. 48). Como que pairando acima das pedras, a protagonista se desvencilha de todo o entulho representado pelos vendedores de itens descartáveis: "calças jeans, brinquedos chineses, ervas medicinais, fitas cassetes, cedês piratas, barracas de frutas e estojos de perfumes paraguaios, quinquilharias cameleônicas: o pregão" (p. 48). Na balbúrdia do comércio de rua, a jovem, alternadamente, se deixa enlevar, depois volta à sua realidade. Encantase com os anéis, mas resiste ao desejo de comprá-los; com fome, opta por um "churrasco grego no pão", sanduíche famoso pelo preço acessível. Encontram-se em todo o fragmento antíteses e sinestesias: a brancura do tênis versus o céu, "uma enorme fazenda cinza"; seu sonho para o futuro, apresentado em discurso indireto livre: "Ah!, um alguém sério, crente, um lar, filhos", distante do local "onde barra-pesada mora, casas tristes barracos, mortos da segunda-feira oblíquos no asfalto, estupros aos sábados, roubos da terça, da quarta" (p. 49). 
A jovem está apta a viver na metrópole, ciente de todo o seu entorno, e demostra sua maturidade ao recriminar mentalmente a colega tola:

Princesa... quer fazer um book? Bonita... Aqui, meu cartão... Truque mais besta! Fernanda, boba, visgou na lábia, até foto pelada, Pra Playboy, Pra Globo, êta! Nem mais viu o ladino, deve ter negociado, tarado não falta, revista de sacanagem aos pregadores em varais pelas calçadas (EEMC, p. 49).

"(Ela" é uma das raras personagens femininas com alguma perspectiva de futuro, ou seja, anunciadoras de uma visão de mundo menos niilista. O parêntese que antecede o título desse fragmento, aberto e sem fecho, aponta para o futuro, em que talvez se concretize seu sonho de um lar feliz, ao lado de marido e filhos, distante da pobreza e da violência.

\section{No recesso do lar}

\section{Uma copa}

Em “32. Uma copa” (EEMC, p. 65-68), a onisciência narrativa é levada ao limite do descritivo, havendo uma única referência à protagonista. No texto descritivo, delineia-se o perfil de dona de casa de subúrbio, que conhecemos, paradoxalmente, por sua ausência em relação ao texto. $\mathrm{O}$ texto remete ao nouveau roman francês, já mencionado:

O motor da geladeira Cônsul Contest 28 branco-gelo sacoleja o silêncio da copa. As paredes azuis, cor da roupa dos anjos, desdobram-se nas lajotas vermelhas de cerâmica, assentadas contra a vontade da dona da casa, que sai na agonia da madrugada para trabalhar, nunca viu os minúsculos cristais de poeira voejando suspensos no facho de raios vespertinos que rompem o vidro fosco do basculhante.

Sobre a geladeira

uma batedeira Walita, de raro uso,

um caderno universitário espiral $(203 \times 280 \mathrm{~mm}$, 96 folhas, uma matéria, 31pautas); baila a Minnie na capa; na primeira folha, letra caprichadíssima, Caderno de Receitas, o miolo virgem

Um ventilador Hiltec assopra o fim do século no relógio-deparede Ferrari (EEMC, p. 65-66, grifo nosso). 
Nesse fragmento, de quase três páginas, a única referência direta às ações da moradora está no trecho grifado acima, pois ela "sai na agonia da madrugada para trabalhar". Não falta ao texto, entretanto, movimento, que é proporcionado pelos objetos: o motor "sacoleja", as paredes "desdobram-se", a poeira "voeja", a luz "rompe" o vidro, o ventilador "assopra" o fim do século. A atribuição de movimento aos objetos culmina com a ilustração da capa do caderno, em que "baila a Minnie". A protagonista sai para trabalhar, porém os objetos proporcionam o detalhamento sobre suas condições de vida, seus gostos, sua família. Depreendemos suas dificuldades financeiras, pois se sujeita a sair para o trabalho de madrugada e sequer pode zelar pela limpeza da copa empoeirada. O padrão de vida modesto reitera-se em numerosos objetos típicos dos lares de classe média baixa, seja pela mobília em que se destacam "uma poltrona de napa", um "rack de madeira aglomerada", seja pelo gosto musical, com dez cedês como "Banda Eva ao vivo" ou "Só pra contrariar", conjunto que também inclui cedês destinados ao público infantil, ou seja, possivelmente à menina cujo retrato decora uma das paredes, de "Grupo Molejo - Não quero saber de ti, ti, ti", "Xuxa, só faltava você", ou ainda pelas bebidas estocadas nessa copa: "sidra doce", "sidra Cereser", "scotch whisky White Horse (falsificado)".

O narrador atribui aos objetos da copa a caracterização dessa moradora, protagonista ausente, mantendo-se, na medida do possível, em um foco narrativo "neutro". A frieza do relato, todavia, não impede que se perceba alguma ternura por essa moradora que sai "na agonia da madrugada para trabalhar", e que, por essa razão, deve ter pouco tempo para usufruir os modestos bens de que dispõe, tanto os bens de consumo (geladeira, ventilador), quanto os bens culturais (cedês), ou ainda a companhia da filha, presente apenas no retrato na parede.

\section{O que quer uma mulher}

Ainda no recesso do lar, passa-se "O que quer uma mulher". O título do fragmento 10, em sentido afirmativo, parece remeter a um lugar comum, porém essa frase, geralmente em tom interrogativo, tem sido atribuída a Freud. Na verdade sua origem se encontra em um texto mais remoto da tradição literária, os Cantos de Cantuária (The Canterbury Tales), escritos por Geoffrey Chaucer no século XIV. Trata-se de um conjunto de narrativas em que os personagens, participantes de uma peregrinação, 
relatam histórias uns aos outros. No "Conto da Mulher de Bath", a narradora remete a um episódio da corte do rei Artur, em que este condenou à morte um fogoso cavaleiro por haver violentado uma donzela. A rainha e outras damas intercederam por ele, que foi condenado à pena de descobrir, no prazo de um ano, "o que querem as mulheres". Saiu o jovem pelo reino a indagar, recebendo respostas as mais variadas, ainda segundo a Mulher de Bath: as mulheres querem riqueza, honra, futilidade, belas roupas, prazeres do leito, adulação, liberdade para "fazer as coisas do nosso jeito, sem que nenhum homem venha apontar as nossas imperfeições" (Chaucer, 1988, p. 114); por outro lado, continua a narradora, "queremos sempre passar por perspicazes e puras", ser consideradas "pessoas discretas e confiáveis", e assim por diante. Sem saber ainda a resposta, com o prazo quase findo, o jovem encontrou na floresta uma megera, que, mediante um pacto, sussurroulhe ao ouvido a resposta, prontamente levada à corte do rei Artur:

"Majestade, de modo geral", disse ele, "o que as mulheres mais ambicionam é mandar no marido, ou dominar o amante, impondo ao homem a sua sujeição. Ainda que me mate, digo que é esse o seu maior desejo. Vossa Majestade agora pode fazer comigo o que quiser: estou a seu dispor" (Chaucer, 1988, p. 115).

A resposta foi plenamente aceita pela corte, tendo sido o jovem absolvido, mas a indagação parece pairar, permanentemente, sem que se comprove nem se rejeite a provável resposta.

Aparentemente, nada há em comum entre a fábula de Chaucer e o fragmento 10. "O que quer uma mulher" transcorre em um espaço e tempo bem delimitados, uma residência de classe média baixa, no início do dia, supostamente o mesmo 9 de maio de 2000 anunciado nas primeiras linhas do livro. A descrição inicial da personagem e do espaço em que vive carrega nas tintas de um desleixo consequente à pobreza:

Ajeitando no nariz os óculos de massa preta, a haste esquerda colada com esparadrapo, as lentes de vidro arranhadas, a mulher penetra com vagar na pequena cozinha, dirige-se à pia, destorce com dificuldade a torneira atipoiada com elástico e barbante entrelaçados e lava um copo-de-requeijão, Frajola persegue o PiuPiu no decalque. [...] Arrastando as pantufas esgarçadas, a sola encaroçoada, a mulher aproxima-se da mesa, toma a garrafa térmica, despeja um gole de café no copo-de-requeijão, rasga um 
pedaço de pão francês dormido, lambuza-o de margarina, volta a recostar-se na pia (EEMC, p. 21-22).

A seguir, a mulher pergunta ao marido sobre o livro que ele lê, e tem como resposta "Microfísica do poder... do Foucault... achei num sebo... na João Mendes". Surpreendido, ele a vê iniciar um longo desabafo, que o narrador mimetiza em linguagem oral, sobre a violência na rua, que presenciara na véspera, finalizando pela decisão tomada: "e eu decidi que não quero mais essa vida pra mim não não quero". Seguem-se frases de inconformismo e revolta, "cansei, nada vale tanto sacrifício trabalhar trabalhar trabalhar pra quê?", “o pior é que a gente não consegue sair dessa merda", "estou cansada, não está vendo? estou cansada muito cansada cansada de viver com um lunático que a única coisa que dá valor na vida é a esses livros que só servem para encher a casa de fungos e adoecer as crianças", e por aí afora, com tentativas de interrupção por parte do marido, quase todas limitadas a um "Mas..." sozinho no parágrafo, que se repete em nada menos que sete vezes.

Se a narrativa de EEMC recria, em microcosmos, o cotidiano da cidade de São Paulo, talvez seja esse o fragmento mais representativo das frustrações da classe média, cujo horizonte está delimitado por ações que mal asseguram sua sobrevivência. Nesse ambiente pobre, exposto à violência da periferia, os ruídos do exterior invadem a residência, revelando a impossibilidade de silêncio ou tranquilidade:

A vizinhança espreguiça-se

$$
\begin{aligned}
& \text { uma discussão, logo abortada } \\
& \text { uma porta que se fecha } \\
& \text { um rádio ligado } \\
& \text { cachorros que latem } \\
& \text { a porta de aço descerrada da padaria } \\
& \text { passos rápidos na calçada } \\
& \text { um bebê que esgoela } \\
& \text { uma sirene, longe, "Polícia?" (EEMC, p. 24) }
\end{aligned}
$$$$
\text { um bebê que esgoela }
$$

Não basta à mulher o carinho do marido ao tentar acalmá-la, ante suas primeiras frases de desabafo, quando ele "tenta envolvê-la nos braços marinhos de sua blusa descosturada" (p. 25), nem quando, pouco antes de sair para o trabalho, "ele preme seu braço com carinho" (p. 27). O longo fragmento mostra a personagem em um momento de epifania, triste epifania, quando se dá conta da incapacidade financeira para realizar seus sonhos de consumo, da falta de acesso a bens culturais 
(salvo livros adquiridos em sebo), da impossibilidade de lazer aos fins de semana. Nesse momento epifânico revela-se o abismo que a separa desse homem

que gasta as manhãs de sábado lavando o cachorro e o quintalzinho latinhas de cerveja e tira-gostos espetados no palito que gasta as tardes de domingo vendo futebol na televisão latinhas de cerveja e tira-gostos espetados no palito

e que dorme em sua cama

e que é o pai de seus filhos

e que

meu deus,

já não reconhece

quem é esse homem quem? (EEMC, p. 27-28)

Ao empregar como recurso a distribuição do texto em pequenos parágrafos, acentuados por anáforas ("e que..."), o narrador enfatiza o estranhamento da personagem, que percebe, subitamente, o distanciamento entre ela e o marido. Sua infelicidade decorre de um conjunto de fatores que o marido sequer chega a compreender. Assim, o título do fragmento remete a outro aspecto: à incapacidade desse homem, professor de cultura acima da média, porém subempregado, para compreender o que quer a mulher, a exemplo da questão posta na fábula de Chaucer. Se, na fábula, "o que as mulheres mais ambicionam é mandar no marido [...], impondo ao homem a sua sujeição", em EEMC o que a mulher mais deseja é afastar-se do marido que ela "já não reconhece" e, enfim, libertar-se dessa vida que a mantém sufocada por monotonia e desesperança.

\section{Considerações finais}

EEMC revela o pessimismo e o niilismo que impregnam a obra de Ruffato. Se ao recorte feito, selecionando apenas figuras femininas, fosse acrescentado um recorte com figuras masculinas, pouca diferença haveria no que se refere à visão de mundo, de um pessimismo sombrio e sem atenuantes. Como um repórter, o narrador recolhe flagrantes muito vivos da metrópole, transcrevendo-os em um modo de ver sem concessões, atento aos sinais de degradação existentes em uma sociedade que parece ter saído de um mundo rural, quase medieval, para cair no turbilhão da sociedade de consumo, em plena era do 
descartável. Descartáveis são todos os indivíduos. Uma perspectiva otimista, se houver, não faz parte da narrativa, sendo relegada ao futuro, como se observou no comentário do fragmento 22 e que seria observável em mais um, cuja personagem está entre as mais jovens de todo o livro: "A menina", no fragmento 38, cuja leveza parece superar todas as agruras do contexto urbano.

Em paralelo à temática da dura vida na metrópole violenta, sobressai outro aspecto notável da prosa de Ruffato: seus recursos estilísticos. Paradoxalmente, ao ler cenas narradas e cenários descritos em toda a sua crueza, depara-se o leitor com um texto portador de estranha poesia: metáforas, sinestesias de cores, sons e texturas, metonímias de rosto e corpo, onomatopeias. Essa harmonia que se estabelece entre um mundo degradado e um texto poético em que esse mundo se recria demonstra, sobejamente, as razões do lugar especial conquistado por Ruffato em nossa literatura contemporânea.

\section{Referências}

AUGÉ, Marc (2012). Não lugares. Introdução a uma antropologia da supermodernidade. Tradução de Maria Lúcia Pereira. 9. ed. Campinas: Papirus.

CANDIDO, Antonio et al. (1995). A personagem de ficção. 9. ed. São Paulo: Perspectiva.

CHAUCER, Geoffrey (1988). Os contos da Cantuária. Tradução de Paulo Vizioli. São Paulo: T.A. Queiróz. (Título original: The Canterbury Tales).

HARRISON, Margueritte Itamar (2007). Uma cidade em camadas. Ensaios sobre o romance Eles eram muitos cavalos. Vinhedo: Horizonte.

LAGARDE, André; MICHARD, Laurent (1988). XXe. Siècle. Les grands auteurs. Anthologie d'histoire littéraire. Paris: Bordas.

MACEDO, Helder (2007). Um livro que exacerba. In: HARRISON, Margueritte Itamar (2007). Uma cidade em camadas. Ensaios sobre o romance Eles eram muitos cavalos. Vinhedo: Horizonte.

RUFFATO, Luiz. (2005) Eles eram muitos cavalos. 3. ed. São Paulo: Boitempo.

SCHØLLHAMMER, Karl E. (2011). Ficção brasileira contemporânea. Rio de Janeiro: Civilização Brasileira. 
WOOD, James. (2012) Como funciona a ficção. Tradução de Denise Bottmann. São Paulo: Cosac Naify.

Recebido em setembro de 2015.

Aprovado em fevereiro de 2016.

\section{resumo/abstract/resumen}

\section{"O que quer uma mulher": figuras femininas em Eles eram muitos cavalos}

\section{Helena Bonito Couto Pereira}

Eles eram muitos cavalos tornou-se um marco na prosa contemporânea, graças à representação da metrópole elaborada com intensa criatividade. A riqueza estilística dessa narrativa expressa-se por meio de recursos como o fragmentarismo, a colagem, as enumerações, o non sense, atualizados a partir da herança modernista. Neste estudo destaca-se o fragmentarismo textual, que cria uma realidade urbana estilhaçada, feita de espaços degradados pelos quais perambulam personagens variadas, algumas integradas à vida urbana, porém desajustadas em seus papeis sociais, outras associadas aos estratos médios e populares, bem como à exclusão social, imersas na pobreza, na violência e na alienação. Observa-se particularmente o desfile de personagens femininas, na dupla perspectiva da diversidade estilística em que são construídas e em relação ao poder de representação socioeconômica e cultural da metrópole contemporânea.

Palavras-chave: personagens femininas, metrópole contemporânea, Luiz Ruffato.

\section{"What does a woman want": female characters in There were many horses}

Helena Bonito Couto Pereira

There were many horses has become a milestone in contemporary Brazilian prose thanks to its highly creative representation of the metropolis, The narrative's rich prose is expressed by textual strategies such as fragmentation, collage, the enumeration, the non-sense, all derived from a modernist heritage, which Ruffato. Updates. This essay highlights the textual fragmentation that creates a shattered urban reality made up by degraded spaces where diverse characters wander, some integrated into the urban life, but nevertheless maladjusted to their social roles, others belonging to the popular and middle social strata, and others still, being subject to social exclusion, submerged in poverty, violence and alienation. In particular this essay looks at a parade of female characters, 
under the dual lens of the stylistic diversity through which they are constructed, and the power of socioeconomics and cultural representations of the contemporary metropolis.

Keywords: female characters, contemporary metropolis, Luiz Ruffato.

\section{"Lo que quiere una mujer": figuras femeninas en Eles eram muitos cavalos}

Helena Bonito Couto Pereira

Eles eram muitos cavalos se ha convertido en un marco en la prosa contemporánea, a causa de su representación de la metrópoli elaborada con intensa creatividad. La riqueza estilística de esa narrativa se expresa a través de recursos como la fragmentación, el collage, las enumeraciones y el non sense, actualizados a partir de una herencia vanguardista. En este estudio se destaca la fragmentación textual que crea una realidad urbana destrozada, hecha de espacios degradados por los cuales deambulan variados personajes, algunos integrados a la vida urbana, aunque disconformes con sus papeles sociales, otros asociados a los estratos medios y populares, igual que otros vinculados a la exclusión social, hundidos en la pobreza, la violencia y la alienación. Se observa particularmente el desfile de personajes femeninos desde la doble perspectiva de la diversidad estilística en que se construyen como en el poder de representación socioeconómica y cultural de la metrópoli contemporánea.

Palabras clave: personajes femeninos; metrópoli contemporánea, Luiz Ruffato. 